\title{
AN EMPIRICAL ANALYSIS OF MONTHLY EFFECT AND TURN OF THE MONTH EFFECT IN INDIAN STOCK MARKET
}

\begin{tabular}{|l|l|l|}
\hline Ms. Shakila B. & Dr. Prakash Pinto & Ms. Babitha Rohith \\
Assistant Professor and Research & Professor and Dean, & Assistant Professor and Research \\
Scholar, & Department of Business & Scholar, \\
Department of Business & Administration, & Department of Business \\
Administration, & St. Joseph Engineering College, & Administration, \\
St. Joseph Engineering College, & Vamanjoor, & St. Joseph Engineering College, \\
Vamanjoor, & Mangalore, Karnataka-575028, & Vamanjoor, \\
Mangalore, Karnataka-575028, India \\
bolarshakila@gmail.com & India & Mangalore, Karnataka-575028, India \\
\hline
\end{tabular}

\begin{abstract}
In an efficient market, all relevant information is fully reflected in stock prices so that no investor is able to make excess profits based on any existing information. This implies that securities are correctly priced. Thus, in an efficient market security prices are said to be correct and provide accurate signals for resource allocation. However, contradiction to this theory several calendar anomalies are reported in the stock markets across the world. One such calendar anomaly documented in financial literature is the monthly effects.

The objective of this paper to examine the existence of monthly effects and turn of the month effect in Indian stock market by using S\&P CNX FMCG Index over the period from April 2007 to March 2013. In this study the daily closing stock prices are converted into daily return by taking natural log of the difference in the price at day $t$ and the price at day $t$-1. Summary statistical measures like mean and standard deviation have been applied to study the distribution pattern of the daily stock returns across a month. To test the significance of the observed results the parametric t-test and the non-parametric Mann-Whitney $U$ test have also been used.

Key words: Calendar Anomaly, Efficient Market, Monthly Effect and Turn-of-the-month Effect.
\end{abstract}

\section{INTRODUCTION}

Exploring the existence of a pattern in stock returns has been an active area of research in finance literature. More specifically, the researchers make an attempt to find out whether any seasonality exists in the stock returns. The presence of seasonalities in stock returns contradicts the Efficient Market Hypothesis (EMH), which states at any given time and in a liquid market, all the available information is fully reflected in security prices (Eugene Fama, 1965). As such, a trader is not able to earn any abnormal profits. However, we find plenty of studies in capital market research documenting the presence of irregularities in the stock return pattern. These irregularities have been termed as market anomalies.
Calendar anomaly is a kind of market anomaly, that is defined as any irregularity or seasonality in the stock returns that exist at different calendar points. Calendar anomalies are related with particular period of time i.e., movement in stock prices from day to day, month to month, year to year etc. Calendar anomalies are based on the assumption that a certain pattern of stock return is formed on the basis of past stock price. This can be used by the investors to earn risk-free profit by trading the stocks. The study of seasonality implies that investors could employ the findings on anomalies to predict the future behaviour of prices (Fama 1965).

There are different kinds of calendar anomalies reported by the researchers across the globe. Some of the recognised calendar anomalies are Day-of-the-week 
effect, Monday Effect, Month of the Year Effect, Monthly effect, Turn-of-the-month effect and Holiday effect. The present study aims at identifying monthly effect and turn-of-the month effect in the Indian stock market by applying two different approaches: calendar day approach and trading day approach.

\section{LITERATURE REVIEW}

Since decades calendar anomalies have been the widely researched area in capital market research. We find numerous studies reported on calendar anomalies nevertheless current study focuses the literature pertaining to monthly effect and turn of the month effect.

Lakonishok \& Smidt (1988), examined the anomalies in the US stock market by using DJIA data from 1897 to 1986 and produced the evidence about semi monthly and turn of the month effects. Jaffe and Westerfield (1989) tested the presence of monthly effects in four countries, namely, the UK, Canada, Japan, and Australia and found that Australian stock returns showed significant monthly effect, whereas, the UK and Canadian stock returns exhibited weak evidence of monthly effect and interestingly they observed reverse monthly effect in Japan. Cadsby (1989) observed turn of the month effect in Canada. Returns at the turn of the month were significantly higher than those during the rest of the year even when the December/January turn of the period was excluded. Ziemba (1991) provided evidence a turn-of-month effect in Japan that runs over the last five and first two trading days of the month. Also the turnof-the-month effect was found to occur over a different sequence of days. Barone (1990) examined the efficiency of Italian stock market and found that low stock returns in the first half and higher return in the second half. Agarwal and Tandon (1994) found unusually large returns around turn of the month and last trading day in 9 countries out of the 18 countries studies, the effect was present in 1970s but not in 1980s. Chotigcat T. and Pandey I.M. (2005) investigated the Monthly effect on stock returns for the stock market in India and Malaysia. The study confirmed the existence of seasonality in stock returns in both capital markets

\section{CNX FMCG INDEX}

The CNX FMCG Index is designed to reflect the behaviour and performance of FMCGs (Fast Moving Consumer Goods) which are non-durable, mass consumption products and available off the shelf. The CNX FMCG Index comprises of 15 stocks from FMCG sector listed on the National Stock Exchange (NSE). The CNX FMCG Index represents about $8.13 \%$ of the free float market capitalization of the stocks listed on NSE and $82.19 \%$ of the free float market capitalization of the stocks forming part of the FMCG universe as on June 30, 2014. The total traded value for the last six months ending June 2014 of all index constituents is approximately $4.62 \%$ of the traded value of all stocks listed on NSE and $78.56 \%$ of the traded value of the stocks forming part of the FMCG universe.

\section{OBJECTIVE OF THE STUDY}

The present study investigates the existence of monthly effect and turn-ofthe-month effect in Indian stock market. 


\section{Hypothesis}

To test the monthly effect following hypothesis are laid down.

1. $H_{o}=$ The daily mean returns of the first half of the month do not significantly differ from the daily mean returns of the second half of the month.

2. $H_{1}=$ The daily mean returns of the first half of the month are significantly greater than the daily mean returns of the second half of the month.

To test the turn-of-the-month effect following are the hypothesis:

1. $H_{o}=$ The daily mean returns at the turn of the month do not significantly differ from

the daily mean returns of the rest of the month.

2. $H_{1}=$ The daily mean returns at the turn of the month are significantly greater than the daily mean returns of the rest of the month.

\section{DATA AND METHODOLOGY}

To examine the presence of monthly effect and turn of the month effect, the current study uses daily closing values of CNX FMCG Index for a period of six years commencing from $1^{\text {st }}$ April 2007 to $31^{\text {st }}$ March 2013. The necessary data have been have been taken from web resource, www.nseindia.com.

The sample data consist of 1,503 calendar days and 1,152 trading days during the study period.

Daily index returns have been computed by applying following formula

$$
\mathrm{R}_{\mathrm{t}}=\ln \frac{P_{t}}{P_{t-1}} \times 100
$$

Where, $\quad \mathrm{R}_{\mathrm{t}}=$ Daily return on the index

$\mathrm{Ln}=$ Natural $\log$ of

underlying market series

$P_{t}=$ Closing value of a given index on a specific trading day $(\mathrm{t})$

And

$P_{t-1}=$ Closing value of a given index on a preceding day $(\mathrm{t}-1)$

Statistical measures like mean and standard deviation have been applied to study the distribution pattern of the daily returns across a month. To test the significance of the observed results the parametric t-test and the non-parametric Mann-Whitney U test have also been used.

\section{RESULTS AND ANALYSIS}

Seasonalities in the stock returns during a month and turn of the month have been documented by a number of researches. The present paper analyses the said anomalies in a more recent context. The current study uses two approaches viz. Calendar day approach and trading day approach, to examine monthly effect and turn of the month effect.

In calendar day approach we use calendar days of the study period i.e, from $1,2, \ldots \ldots 30,31$ to test the anomalies and in trading day approach trading days before and after the commencement of the month are considered.

There are in total 1,503 calendar days and 1,152 trading days identified for the study period.

The mean daily returns along with relevant statistics of CNX FMCG Index for various calendar days of the month are presented in Table 1. 
Asia Pacific Journals

Table: 1 Means, Standard Deviations, and t-statistics of Daily Returns of CNX FMCG Index by Calendar day of the month.

\begin{tabular}{|c|c|c|c|c|}
\hline $\begin{array}{c}\text { Calendar } \\
\text { Days }\end{array}$ & Mean Returns & $\begin{array}{c}\text { Std. } \\
\text { Deviation }\end{array}$ & $\begin{array}{c}\text { No.of } \\
\text { Observations }\end{array}$ & t-statistics \\
\hline 1 & 0.00435 & 1.37077 & 44 & 0.764 \\
\hline 2 & --0.02482 & 1.03233 & 43 & 0.875 \\
\hline 3 & 0.15508 & 1.43720 & 50 & 0.449 \\
\hline 4 & 0.20951 & 1.42109 & 53 & 0.308 \\
\hline 5 & -0.25879 & 1.17228 & 52 & 0.118 \\
\hline 6 & --0.11713 & 1.36024 & 47 & 0.558 \\
\hline 7 & 0.06068 & 1.47961 & 51 & 0.771 \\
\hline 8 & --0.14114 & 1.50128 & 50 & 0.509 \\
\hline 9 & 0.10049 & 1.44632 & 50 & 0.625 \\
\hline 10 & --0.06900 & 1.33837 & 48 & 0.723 \\
\hline 11 & -0.27968 & 1.22760 & 52 & 0.107 \\
\hline 12 & 0.00383 & 1.06104 & 49 & 0.980 \\
\hline 13 & 0.37756 & 1.27489 & 52 & 0.038 \\
\hline 14 & 0.37728 & 0.98453 & 47 & 0.012 \\
\hline 15 & -0.07973 & 1.24904 & 47 & 0.664 \\
\hline 16 & 0.19033 & 1.31613 & 52 & 0.302 \\
\hline 17 & --0.24293 & 1.52440 & 51 & 0.261 \\
\hline 18 & 0.20932 & 1.51630 & 52 & 0.324 \\
\hline 19 & 0.02649 & 1.31309 & 48 & 0.889 \\
\hline 20 & --0.10151 & 1.07918 & 47 & 0.522 \\
\hline 21 & --0.09268 & 1.71986 & 50 & 0.705 \\
\hline 22 & --0.02104 & 1.69095 & 52 & 0.929 \\
\hline 23 & 0.34221 & 1.61036 & 50 & 0.139 \\
\hline 24 & 0.08628 & 1.55094 & 49 & 0.699 \\
\hline 25 & 0.38447 & 1.32440 & 49 & 0.048 \\
\hline 26 & 0.03333 & 1.20260 & 47 & 0.850 \\
\hline 27 & --0.00404 & 1.43962 & 50 & 0.984 \\
\hline 28 & 0.49684 & 1.26733 & 50 & 0.008 \\
\hline 29 & 0.31687 & 1.17243 & 47 & 0.070 \\
\hline 30 & 0.15415 & 1.13390 & 45 & 0.367 \\
\hline 31 & 0.45080 & 1.46081 & 29 & 0.108 \\
\hline $\begin{array}{l}\text { Global } \\
\text { statistics }\end{array}$ & 0.08217 & 1.4635 & 1503 & \\
\hline
\end{tabular}

It appears from Table 1 the highest mean calendar day return is recorded on the $28^{\text {th }}$ calendar day of the month amounting to 0.49684 percent, which is almost 6.04 
times of global mean return of all calendar days taken together. It is closely followed by the $31^{\text {st }}$ calendar day of the month. The lowest and the negative mean calendar day return is recorded on the eleventh day i.e., -0.27968 .

The present study uses trading day approach as well to examine the monthly pattern of stock returns exist in Indian stock market. Table 2 shows the mean returns of the eight trading days before and after the start of each month (-8 to -1 and 1 to 8 ), where +1 is the first trading day of each month and -1 is the last trading day of the previous month. The days that do not fall in the intervals ( 1 to 7 ) and (-7 to -1$)$ are ignored.

Table :2 Means, Standard Deviations, and t-statistics of Daily Returns of CNX FMCG Index by Trading day of the month

\begin{tabular}{|l|l|l|l|l|}
\hline Trading Days & Mean & $\begin{array}{l}\text { Standard } \\
\text { Deviation }\end{array}$ & $\begin{array}{l}\text { No. of } \\
\text { Observations }\end{array}$ & t-statistics \\
\hline-8 & 1.59814 & -0.06693 & 72 & 0.723 \\
\hline-7 & 1.45448 & 0.31204 & 72 & 0.073 \\
\hline-6 & 1.19061 & 0.02125 & 72 & 0.880 \\
\hline-5 & 1.51265 & 0.24797 & 72 & 0.169 \\
\hline-4 & 1.22898 & 0.11202 & 72 & 0.442 \\
\hline-3 & 1.17520 & 0.16477 & 72 & 0.238 \\
\hline-2 & 1.23324 & 0.01865 & 72 & 0.898 \\
\hline-1 & 1.34481 & 0.52124 & 72 & 0.002 \\
\hline 1 & 1.55889 & -0.01817 & 72 & 0.921 \\
\hline 2 & 1.05931 & 0.14095 & 72 & 0.263 \\
\hline 3 & 1.25540 & -0.01456 & 72 & 0.922 \\
\hline 4 & 1.40695 & -0.00982 & 72 & 0.953 \\
\hline 5 & 1.64940 & -0.04749 & 72 & 0.808 \\
\hline 6 & 1.33754 & -0.06007 & 72 & 0.704 \\
\hline 7 & 1.41706 & 0.10873 & 72 & 0.517 \\
\hline 8 & 1.06316 & 0.01374 & 72 & 0.913 \\
\hline Global Mean & 1.35441 & 0.0902 & 1,152 & \\
\hline
\end{tabular}

Table 2 depicts daily mean return estimated from 72 daily observations of each trading day and standard deviation and $\mathrm{t}$ - values for each trading day of the study period for CNX FMCG Index. It is seen from the above table that the highest mean return is recorded on the last trading day $(-1)$ of the previous month, amounting to 0.52124 percent. Which is about six times the global mean. It is also observed that mean returns are greater on the seventh trading day (-7) of the previous month i.e.,0.31204 percent and fifth day (5) of the previous month i.e.,0.24797 percent of the previous month, indicating higher mean returns towards the end of the 
month. We also find negative mean returns during the commencement of the month (1, 3,4,5,6 and 7 trading days).

\section{Monthly Effect}

To verify whether the mean return at the first half of the month is significantly higher than the second half, we apply both calendar day and trading day approaches.
In the calendar day approach, first half of the month includes thirtieth and the thirty first calendar days of the previous month and the first to thirteenth calendar days of the following month, totalling fifteen calendar days. The second half of the month consists of fourteenth to the twenty ninth calendar days in total sixteen calendar days.

Table 3: Mean and S.D. of Returns for the First Half of the Calendar Month and Second Half of the Calendar Month and t-statistics for the difference of these Two Means of CNX FMCG Index.

\begin{tabular}{|l|l|l|}
\hline & $\begin{array}{l}\text { Average Returns Across } \\
\left.\text { Calendar Days. ( } 1^{\text {st }} \text { half }\right) \\
(30,31,1 \ldots 13)\end{array}$ & $\begin{array}{l}\text { Average Returns Across } \\
\text { Calendar days. (2 } \\
(14 \text { to 29) }\end{array}$ \\
\hline Mean & 0.03271 & 0.11102 \\
\hline Standard Deviation & 1.32835 & 1.47458 \\
\hline No. of Observations & 708 & 638 \\
\hline \multicolumn{3}{|c|}{$\begin{array}{c}\text { M-statistics } 0.306 \\
\text { U (Z value }) \quad 0.132 \\
\end{array}$} \\
\hline
\end{tabular}

Table 3 exhibits the mean, standard deviation and other relevant statistics for the first half of and second half of the calendar month. As per the above table the mean returns of the first half of the month is (0.03271) is lower than that of the second half $(0.1110$ percent $)$ and also $\mathrm{T}$ values for two halves indicate that there is no significant difference in the mean return of first and half of the calendar month. The non-parametric Mann-Whitney U test also indicates the same result.

Under trading approach, the first half of the trading month includes last trading day of the previous month and first seven days of the following month. The second half begins from the eighth day to the second last trading day of the month.

Table 4: Mean and S.D. of Returns for the First Half of the Trading Month and Second Half of the Trading Month and $t$-statistics for the difference of these Two Means of CNX FMCG Index.

\begin{tabular}{|l|l|l|}
\hline & $\begin{array}{l}\text { Average Returns for the } \\
\text { First Half the Trading } \\
\text { Month }(-1 \text { to } 7)\end{array}$ & $\begin{array}{l}\text { Average Returns for the } \\
\text { Second Half the Trading } \\
\text { Month }(8 \text { to }-2)\end{array}$ \\
\hline Mean & 0.07760 & 0.10294 \\
\hline
\end{tabular}


Asia Pacific Journals

\begin{tabular}{|l|l|l|}
\hline Standard Deviation & 1.39231 & 1.31662 \\
\hline No. of Observations & 576 & 576 \\
\hline \multicolumn{3}{|c|}{ T-statistics } \\
Mann-Whitney & 0.751 \\
& U (Z value) & 0.680 \\
\end{tabular}

Table 4 depicts the relevant statistics of the two halves of a trading month. The mean daily return of the first half is 0.07760 percent and that of the second half is 0.10294 percent. This implies that there is no significant difference between mean returns of two halves of the trading month. A one-tailed t-test of difference of means between these two groups also validate the non-existence of significant difference in the mean returns.

Thus, both the approaches accept the null hypothesis that the daily mean returns of the first half of the month do not significantly differ from the daily mean returns of the second half of the month.

Table 5: Mean and S.D. of Returns for the Turn of the Month and Remaining Days of the Calendar Month and t-statistics for the difference of these Two Means of CNX FMCG Index.

\begin{tabular}{|l|l|l|}
\hline & $\begin{array}{l}\text { Average Returns for the } \\
\text { Turn of the Calendar } \\
\text { Month (30 to 31,1,to 2) }\end{array}$ & $\begin{array}{l}\text { Average Returns for the Rest } \\
\text { of the Calendar Month (3 to } \\
\text { 29) }\end{array}$ \\
\hline Mean & 0.11884 & 0.07412 \\
\hline Standard Deviation & 1.24146 & 1.37778 \\
\hline No. of Observations & 161 & 1,329 \\
\hline \multicolumn{2}{|c|}{0.670} \\
\\
$\begin{array}{c}\text { T-statistics } \\
\text { Mann-Whitney } \\
\text { U (Z value) }\end{array}$ \\
\hline
\end{tabular}

Table 5 exhibits the mean, standard deviation, the t-statistics for the difference between two means, and Mann-Whitney $U$ ( $\mathrm{Z}$ value). It is seen from the above table the daily return for the turn of the month 0.11884 percent which is only 1.6 times

\section{Turn-of-the Month Effect.}

The present study also tests the turn-of-the month effect by employing calendar day approach and trading day approach.

In the calendar day approach, the turn of the month includes thirtieth and thirty first calendar days of the previous month and first and second (30,31,1 and 2) calendar days of the following month. Whereas the rest of the month begins from third to twenty-ninth (3 to 29) calendar days of the month, totalling twenty nine days. greater than the daily return of the rest of the calendar month. T-test and MannWhitney tests also confirm that there is no significant difference in the mean returns of the turn of the month and that of rest of calendar month. 
In trading approach, the turn-of-the month is defined the period from the last two trading days of the previous month to the first two trading days of the current month.
$(-2,-1,+1,+2)$. Rest of the month is represented by 3 to 8 and -8 to -3 trading days.

Table 6: Mean and S.D. of Returns for the Trading Days at the Turn of the Month and Rest of the Month and t-statistics for the difference of these Two Means of CNX FMCG Index.

\begin{tabular}{|l|l|l|}
\hline & $\begin{array}{l}\text { Average Returns for the } \\
\text { Trading days at the } \\
\text { Turn of the Month }(-2 \\
\text { to 2) }\end{array}$ & $\begin{array}{l}\text { Average Returns for the } \\
\text { Trading days for the Rest of } \\
\text { the month. (3 to 8 to -8 to - } \\
3)\end{array}$ \\
\hline Mean & 0.16567 & 0.04279 \\
\hline Standard Deviation & 1.3222 & 1.35091 \\
\hline No. of Observations & 288 & 864 \\
\hline \multicolumn{2}{|c|}{$\begin{array}{c}\text { T-statistics } \\
\text { Mann-Whitney } \\
\text { U (Z value) }\end{array}$} \\
\end{tabular}

It is seen from Table 6 the daily returns for the turn of the month is 0.1656 , which is greater than the daily returns for the rest of the month is i.e, 0.04279. However, tstatistics indicates that there is no significant difference in the mean returns of two subsets.

Therefore, we accept the null hypothesis under both the approaches stating that the daily mean returns at the turn of the month do not significantly differ from the daily mean returns of the rest of the month.

\section{CONCLUSION}

The paper investigates the presence of monthly effect and turn-of-the month effect in CNX FMCG Index, sectoral index of NSE, India for the period between $1^{\text {st }}$ April 2007 and $31^{\text {st }}$ March 2013. The study uses calendar day approach and trading day approach to test the monthly pattern in the select index. The empirical findings suggest that there is no significant of the month.

\section{References:}

[1] Agrawal, A., \& Tandon, K. (1994). Anomalies or Illusions? Evidence from Stock Markets in Eighteen Countries. Journal of International Money and Finance, 13, 83-106.

[2] Ariel, R. (1987). A Monthly Effect in Stock Returns. Journal of Financial Economics, 18, 161-174.

[3] Barone, E. (1990). The Italian Stock Market: Efficiency and Calendar Anomalies . Journal of Banking and Finance, 14, 483-510.

[4] Bodla, B. S., \& Jindal, K. (2006). Monthly Effects in Stock Returns:New Evidence from Indian Stock Market. The ICFAI Journal of Banking and Finance, 12(7), 0513. 
[5] Boudreaux, D. O. (1995). The Monthly Effect in International Stock Markets : Evidence and Implications. Journal of Financial and Strategic Decisions, 8(1), 1520.

[6] Cadsby, C. B. (1989). Canadian Calendar Anomalies and the Capital Asset Pricing Model. A reappraisal of the efficiency of financial markets, 199-266.

[7] Chen, H., \& Chua, A. (2011). The Turn of the Month Anomaly in the age of ETFs: A Reexamination of Return-Enhancement Srategies. Journal of Financial Planning, 24(4), 62-67.

[8] Chotigcat, T., \& Pnadey, I. M. (2005). Seasonality in Asia's Emerging Stock Markets: India and Malaysia. International Trade and Finance Association 15th International Conference.

[9] Dhankar, R. S., \& Chakraborthy, M. (2009). Seasonality in Indian Stock Market: A re-examination of January Effect. Asia Pacific Business Review, 5, 28-42.

[10] Fama, E. F. (1965). The Behaviour of Stock Market Prices. Journal of Business, 38, 34-105.

[11] Hensel, C. R., \& Ziemba, W. T. (1996). Investment Results from Exploiting Turn-of-the- Month Effects. Journal of Portfolio Managemnt, 17-23.

[12] Jaffe, J. F., \& Westerfield, R. (1989). Is There a Monthly Effect in Stock Market Returns. Journal of Banking and Finance, 13, 237244.
[13] Karmakar, M., \& Chakraborty, M. (2000). A Trading Strategy for the Indian Stcock Market:Analysis and implications. Vikalpa, 24(4), 27-37.

[14] Kolahi, F. (2006). Turn of the Month Effect for the European Stock Markets. Simor Fraster University, Management.

[15] Lakonishok, J., \& Smidt, S. (1988). Are Seasonal Anomalies Real? A Ninety- Year Perspective. Review of Financial Studies, 1, 403-425.

[16] Lucey, B. M., \& Whelan, S. (2004). Monthly and Semi-Annual Seasonality in the Irish Equity Market 1934-2000. Applied Financial Economics, 14, 203-208.

[17] Mangala, D., \& Sharama, S. K. (2007). Are there Monthly and Td Implicationsurn-of-the-Month Effects in Indian Stock Market?: Evidence an. Paradigm, 16-22.

[18] Mehta, K., \& Chaner, R. (2009). Seasonality in Indian Stock Market: A re-examination of January Effect. Asia-Pacific Business Review, 5(4), 28-42.

[19] Mitchell, J. D., \& Ong, L. L. (2006). Seasonalities in Chinas's Stock Markets: Cultural or Structural? IMF Working Paper.

[20] Patel, J. B., \& Evans, D. A. (2003). Seasonal Stock Patterns in the Seventh Industrialised Nations. The Journal of Applied Business Research, 19(3), 111-120.

[21] Wong, K. A. (1995). Is there an intra-month Effect on Stock Returns in Developing Stock 
Asia Pacific Journals

Markets? Applied Financial

Economics, 5, 285-289.

[22] Ziemba, W. T. (1991). Japanese

Security Market Regularities:

Monthly, Turn of the Month and

Year, Holiday and Golden Day

Effects. Japan and the World

Econom, 3, 119-146. 